\title{
The International Plant Sentinel Network: an update on phase 2
}

\author{
Kate Marfleet $^{1}$ \& Suzanne Sharrock ${ }^{2}$
}

\begin{abstract}
Invasive plant pests and pathogens pose a considerable threat to plant health worldwide. With increasing globalisation of trade in plants and plant material, and the effects of climate change, this threat is predicted to continue to rise. In recent years, there has been a sharp increase in the number of these harmful invasive organisms which cause large-scale environmental and economic damage. A significant issue in managing this threat is predicting which organisms will pose a threat in the future. Sentinel plants are individuals found outside their native ranges that can be surveyed for damage by organisms they would not otherwise encounter. Monitoring plant sentinels can build knowledge and understanding of pest/host relationships to support the development of management plans and risk assessments. Botanic gardens and arboreta, whose collections are estimated to include 30-40 per cent of all known plant species, many of which are exotic, are unique and under-utilised resources that can support sentinel research. The International Plant Sentinel Network (IPSN) consists of botanic gardens and arboreta, National Plant Protection Organisations (NPPOs) and plant health scientists who collaborate to provide an early-warning system for new and emerging plant pests and pathogens. Members provide scientific evidence to NPPOs to inform plant health activities and thus help safeguard susceptible plant species. In the UK, the IPSN conducts research activities prioritised by a Research and Development committee and preliminary findings of recent research activities are outlined in this paper. The IPSN also focuses on increasing knowledge and awareness, seeking best practice, developing standardised approaches and providing training materials and methodologies for monitoring and surveying to enable gardens to contribute to sentinel research. Through multi-disciplinary collaboration and information sharing the IPSN aims to reduce the risk that alien invasive pests and pathogens pose to global plant health.
\end{abstract}

\section{Introduction}

Plant pests and pathogens present a significant risk to global plant health, and this threat is ever increasing due to the growing global trade of plant material and the impacts of climate change. Countries are using a number of phytosanitary measures in order to reduce this risk, including Pest Risk Analysis (PRA), which assesses the potential impact a species could have on plant health were it to be introduced into a new region.

A key issue in identifying and assessing plant health risks is that the most serious

\footnotetext{
${ }^{1}$ Kate Marfleet is Seed Conservation and Plant Health Network Coordinator at Botanic Gardens Conservation International.

Address: Descanso House, 199 Kew Road, Richmond, TW9 3BW, UK.

Email: kate.marfleet@bgci.org

${ }^{2}$ Suzanne Sharrock is Head of Global Programmes at Botanic Gardens Conservation International.

Address: as above.
} 
invasive alien species are often not pests in their region of origin. For example, Cryphonectria parasitica (chestnut blight) was accidentally introduced into the USA and devastated sweet chestnut forests there in the first half of the twentieth century, despite being relatively harmless in Asia where it originated (Anagnostakis, 1987). For this reason the majority of the most damaging alien pests and pathogens that have or have had a dramatic impact on temperate forests would not have been predicted as pests by conventional methods for assessing plant health risks.

It is estimated that 30 per cent of known plant species and over 41 per cent of known threatened species are growing in the living collections of botanic gardens and arboreta (BG\&A) throughout the world (Mounce et al., 2017). Often, species are maintained in gardens outside the country or even the continent in which they are native. These expatriate plants can act as standing sentinels for potentially invasive pests and pathogens. Monitoring these sentinel plants for damage by pests and pathogens not yet present in their native countries can provide vital information on potential future pest threats (Mansfield et al., 2019).

The International Plant Sentinel Network (IPSN) was established by Botanic Gardens Conservation International (BGCI) in 2013. The main objective of the IPSN is to act as an early warning system, identifying new and emerging pest and pathogen risks. It aims to do this by developing a network of interested BG\&A around the world, linked to plant protection scientists and National Plant Protection Organisations (NPPOs).

A comprehensive introduction to the IPSN was published in this journal in 2015 (Barham et al., 2015). This article provides an update on activities in Phase 2 of the IPSN.

\section{The Euphresco project - IPSN phase 2}

Phase 2 of the IPSN was accepted as a

Euphresco (European Phytosanitary Research Coordination) project in 2017. Euphresco is a network of organisations funding research projects and coordinating national research in the phytosanitary area. The overall goal of Euphresco is to support coordination and collaboration in the area of phytosanitary research, and to become a strong, long-term network of funders that fully incorporate existing and new members. As a Euphresco partner, the UK's Department for Food, Environment and Rural Affairs (Defra) is providing support to $\mathrm{BGCl}$ to coordinate the IPSN project for a three-year period (2017-2020).

The IPSN Euphresco partners (shown in Table 1) form a network of researchers contributing to sentinel research work. By working together, the partners provide access to an expanded pool of expertise, diagnostic services and funding. Supported by $\mathrm{BGCl}$, Euphresco partners are helping to establish participation from and strong links to BG\&A within their own (and potentially neighbouring) countries.

\section{The IPSN network}

The IPSN itself is a network of BG\&A with an interest in, and commitment to, biosecurity and general plant health issues. The network presently (July 2019) includes over 40 BG\&A located in 17 countries around the world (IPSN, 2014). These gardens provide a first point of contact for information on specific plant-pest associations and are willing to carry out surveys as requested by member countries. The network acts on a reciprocal basis, with gardens, in association with their NPPO, both providing and requesting information on the impacts of pests and pathogens on specific host species. 


\begin{tabular}{|c|c|c|c|}
\hline Institute & Abbreviation & Contact & Activity \\
\hline $\begin{array}{l}\text { Botanic } \\
\text { Gardens } \\
\text { Conservation } \\
\text { International }\end{array}$ & $\mathrm{BGCl}$ & $\begin{array}{l}\text { Kate Marfleet / } \\
\text { Suzanne } \\
\text { Sharrock }\end{array}$ & Coordination, capacity building, dissemination \\
\hline $\begin{array}{l}\text { Agentschap } \\
\text { Plantentuin } \\
\text { Meise, } \\
\text { Belgium }\end{array}$ & APM & Anne Ronse & $\begin{array}{l}\text { Surveying and identifying emerging pests } \\
\text { and selected pest organisms in Belgian BG\&A, } \\
\text { including laboratory testing using molecular } \\
\text { methods } \\
\text { Face-to-face workshops for training garden staff } \\
\text { and providing key networking opportunities } \\
\text { Developing a Belgian Plant Sentinel Network, } \\
\text { integrated into the IPSN }\end{array}$ \\
\hline $\begin{array}{l}\text { AgResearch } \\
\text { Limited, New } \\
\text { Zealand }\end{array}$ & B3 & Mark McNeill & $\begin{array}{l}\text { Identifying overseas BG\&A with New Zealand } \\
\text { native plants } \\
\text { Identifying New Zealand sentinel plants located } \\
\text { in 'hotspots' where severe plant pathogen or pest } \\
\text { outbreaks are occurring } \\
\text { Collecting, collating and analysing data on pest } \\
\text { and pathogen incidence and impact from sentinel } \\
\text { plant locations } \\
\text { Coordinating and facilitating links with Chinese } \\
\text { researchers and botanic gardens } \\
\text { Working with Chinese collaborators to access } \\
\text { information published in Chinese of value to NZ } \\
\text { biosecurity and conservation authorities } \\
\text { Developing a project for one or more Chinese- } \\
\text { speaking students who could work in a reciprocal } \\
\text { way to survey and identify plant pests and } \\
\text { conduct research projects }\end{array}$ \\
\hline $\begin{array}{l}\text { Animal } \\
\text { Plant Health } \\
\text { Inspection } \\
\text { Service, USA }\end{array}$ & APHIS & $\begin{array}{l}\text { Heather } \\
\text { Hartzog / } \\
\text { Heather } \\
\text { Moylett }\end{array}$ & $\begin{array}{l}\text { Providing expertise in risk analysis, pest data } \\
\text { information management and official pest } \\
\text { reporting requirements }\end{array}$ \\
\hline $\begin{array}{l}\text { CABI }(\mathrm{CH}), \\
\text { Switzerland }\end{array}$ & & René Eschen & $\begin{array}{l}\text { Creating a database of pests and pathogens on } \\
\text { selected tree species in botanical gardens across } \\
\text { Europe and other continents } \\
\text { Identifying numbers of trees and locations (i.e. } \\
\text { botanical gardens) that should be included in } \\
\text { surveys to obtain a representative overview of } \\
\text { pests on a tree species. }\end{array}$ \\
\hline $\begin{array}{l}\text { Central } \\
\text { Institute for } \\
\text { Supervising } \\
\text { and Testing in } \\
\text { Agriculture, } \\
\text { Czech } \\
\text { Republic }\end{array}$ & UKZUZ & $\begin{array}{l}\text { Vladislav } \\
\text { Rasovsky }\end{array}$ & $\begin{array}{l}\text { Raising awareness of new phytosanitary risks } \\
\text { Developing a link between botanical gardens } \\
\text { and diagnostic labs for diagnosis of new pests, } \\
\text { including a simple tool for this communication } \\
\text { Surveying and monitoring new and emerging } \\
\text { pests in BG\&A in the Czech territory }\end{array}$ \\
\hline
\end{tabular}

Table 1 Partners included in the IPSN Euphresco project and their key activities. 


\begin{tabular}{|c|c|c|c|}
\hline $\begin{array}{l}\text { Consiglio per } \\
\text { la ricerca in } \\
\text { agricoltura } \\
\text { e l'analisi } \\
\text { dell'economia } \\
\text { agrarian, Italy }\end{array}$ & CREA & $\begin{array}{l}\text { Elisabetta } \\
\text { Gargani / } \\
\text { Sauro Simoni }\end{array}$ & $\begin{array}{l}\text { Providing Italian BG\&A with information about } \\
\text { new and emerging threats or susceptible host } \\
\text { species } \\
\text { Contributing to training material related to } \\
\text { arthropods and nematodes }\end{array}$ \\
\hline $\begin{array}{l}\text { Core Facility } \\
\text { Botanical } \\
\text { Garden, } \\
\text { Faculty for } \\
\text { Life Sciences, } \\
\text { University } \\
\text { of Vienna, } \\
\text { Austria }\end{array}$ & UNIVIE & Michael Kiehn & $\begin{array}{l}\text { Testing options for the detection and } \\
\text { identification of potential pests and invasive } \\
\text { organisms, and identifying any related problems } \\
\text { Bringing the Austrian Consortium of Botanic } \\
\text { Gardens into the project }\end{array}$ \\
\hline $\begin{array}{l}\text { Julius Kuehn } \\
\text { Institute, } \\
\text { Federal } \\
\text { Research } \\
\text { Centre for } \\
\text { Cultivated } \\
\text { Plants, } \\
\text { Germany }\end{array}$ & JKI & $\begin{array}{l}\text { Uwe } \\
\text { Starfinger }\end{array}$ & $\begin{array}{l}\text { Further developing the 'trap plant approach' by } \\
\text { refining protocols for choosing plant species, } \\
\text { planting and assessing damage }\end{array}$ \\
\hline $\begin{array}{l}\text { Plant Health } \\
\text { Australia }\end{array}$ & PHA & Greg Fraser & $\begin{array}{l}\text { Access to the virtual coordination centre of the } \\
\text { IPSN for collation and management of data }\end{array}$ \\
\hline $\begin{array}{l}\text { Royal Botanic } \\
\text { Garden } \\
\text { Edinburgh, } \\
\text { Scotland }\end{array}$ & RBGE & $\begin{array}{l}\text { Katherine } \\
\text { Hayden }\end{array}$ & $\begin{array}{l}\text { Assessing and mitigating risk of cryptic soil } \\
\text { pathogens in conservation horticulture } \\
\text { Enacting experimental sentinel plantings } \\
\text { Developing and delivering public outreach and } \\
\text { professional workshops }\end{array}$ \\
\hline $\begin{array}{l}\text { Swedish } \\
\text { University of } \\
\text { Agricultural } \\
\text { Sciences, } \\
\text { Sweden }\end{array}$ & SLU & Jonàs Oliva & $\begin{array}{l}\text { Provide expertise in monitoring tree pathogens by } \\
\text { the use of molecular methods }\end{array}$ \\
\hline $\begin{array}{l}\text { Universitat de } \\
\text { Lleida, Spain }\end{array}$ & UdL & Xavier Pons & $\begin{array}{l}\text { Surveys in Lleida Botanical Garden } \\
\text { Developing training material related to arthropods } \\
\text { and arthropod pest surveys in botanical gardens } \\
\text { in its geographical area } \\
\text { Developing a Spanish Plant Sentinel Network }\end{array}$ \\
\hline $\begin{array}{l}\text { University of } \\
\text { Copenhagen, } \\
\text { Denmark }\end{array}$ & $\mathrm{UCPH}$ & $\begin{array}{l}\text { Hans Peter } \\
\text { Ravn }\end{array}$ & $\begin{array}{l}\text { Providing an overview of our knowledge on the } \\
\text { fate of plants introduced into our BG\&A and } \\
\text { identifying specific information regarding their } \\
\text { establishment } \\
\text { Providing a list of native tree species for } \\
\text { monitoring overseas }\end{array}$ \\
\hline $\begin{array}{l}\text { University of } \\
\text { Tuscia-DIBAF, } \\
\text { Italy }\end{array}$ & UNITUS & $\begin{array}{l}\text { Anna Maria } \\
\text { Vettraino }\end{array}$ & $\begin{array}{l}\text { Providing Italian BG\&A with information about new } \\
\text { and emerging threats or susceptible host species } \\
\text { Analysing the structure of the fungal community } \\
\text { of Pinus seeds from BG\&A in Europe and abroad }\end{array}$ \\
\hline
\end{tabular}




\section{IPSN surveys}

Some examples of recent surveys conducted through the IPSN are provided below. These surveys rely on data maintained by $\mathrm{BGCl}$ in its PlantSearch database. ${ }^{3}$ This database is the only global database of living plant, seed and tissue collections in BG\&A and allows gardens with certain species in their collections to be identified.

\section{Xylella fastidiosa}

Plant and Food New Zealand has requested information from BG\&A with native New Zealand plants in their collections in regions where Xylella fastidiosa is present or likely to spread. All IPSN member gardens in that area were contacted along with other gardens that were identified according to GardenSearch records as being in the target area. A questionnaire supplied by Plant and Food New Zealand was distributed to the identified $B G \& A$. To date thirty botanic gardens have been contacted and out of these nine have provided survey results with no records of $X$. fastidiosa found on New Zealand native plants.

\section{Spittlebug survey}

In May and June 2017 the IPSN ran a campaign on Twitter with the aim of improving understanding of host plants of spittlebugs in the UK. Spittlebugs are potential vectors of the bacterial disease Xylella fastidiosa. This disease is not currently found in the UK, but Defra and the UK plant health service are gathering information to ensure that the risks relating to the pathogen are understood. Members of the public were asked to look for the characteristic frothy 'spittle' on plants and provide a photograph of the plant on which it was found (no information on the taxonomy of the spittlebugs was collected). Botanical experts then identified the plants photographed. In total, 65 tweets were received from all over the UK. Eighty-six species were identified as spittlebug hosts. A summary of results can be found in Fig. 1 with a full report available on the IPSN website. ${ }^{4}$ The campaign was a useful demonstration of crowdsourcing to gather new information for the plant health service and provided a collaboration between botanical experts and plant health scientists. The results were presented at the PlantNetwork Plant Pest and Disease Management training day that took place on 3-4 October 2017. The spittlebug poster that was developed in English as part of the survey has been translated into Italian for use by the Italian Euphresco partners. Fig. 2 shows an image of a survey in progress.

\section{IPSN resources}

$\mathrm{BGCl}$ has developed a suite of resources to support general biosecurity and pest and disease monitoring in botanic gardens (Fig. 3). These range from PowerPoint presentations to poster templates and 'how to' guides. Several have been translated into other languages such as Chinese and Russian. These resources are all available to IPSN members on the IPSN website, and available to non-members on request (IPSN, 2014).

Table 2 provides a list of some of the key resources developed by $\mathrm{BGCl}$ in the framework of the IPSN. 


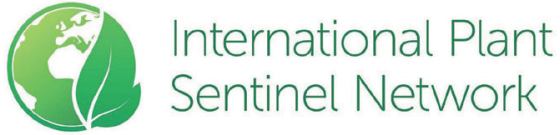

A global network of botanic gardens, arboreta, plant health institutes and National Plant Protection Organisations (NPPOs) working together to provide an early warning system for new and emerging

Within temperate forests the majority of the most damaging alien pests and diseases that have, or are currently having, a devastating impact on tree populations are considered harmless within their native areas (Kenis et al., 2011). A recent example of this is the introduction into the U.S. of Emerald ash borer (Agrilus planipennis) which has devastated North American ash tree populations despite the fact it is not considered an important pest in its native Asian range (Fagan et al., 2008). Identifying potential threats to plant species before a pest is introduced can drastically improve the success of eradication or control programmes, and may even prevent their introcuction in the first place.

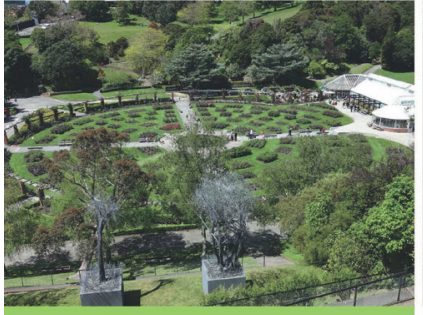

Sentinel plants

Plant species maintained outside of their natural ranges (e.g. in botanic gardens and arboreta) offer a unique opportunity to understand and predict potential threats to plant health. So-called sentinels can be monitored for damage by pests present in their current location, but which are not currently introduced into the sentinel's country of origin. Monitoring sentinels can provide vital information about identified as a risk, as well as help identify potential future threats.

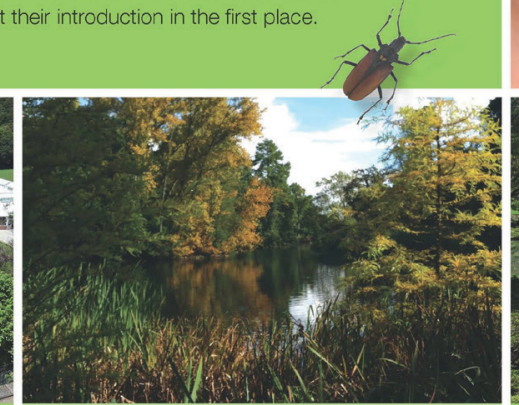

The network

The IPSN is a developing network of plant protection scientists, NPPOs and botanic gardens and arboreta around the world which:

- Develops standardised methodologies for monitoring and surveying for damaging plant pests and pathogens;

- Provides training materials to increase capacity among member gardens:

- Seeks and shares examples of best practise; - Facilitates access to diagnostic support;

- Develops databases in order to share and store information; and

- Facilitates contact and communication between botanic gardens, arboreta and personnel working within plant health in the local area. pest and disease threats key organisms already

Authors

Elie Barham', Suzanne Sharrock', Charles Lane², Richard Baker Organisations

Botaric Gardens Conservation International 199 Kew Road, Richmond, TWV 3BW, UK 'Fera, Sand Hutton, York, YO4 1 lZZ, UK and Rural Affairs (DEFRA) Sand Hutton, York, YO41 $11 Z$ Z UK
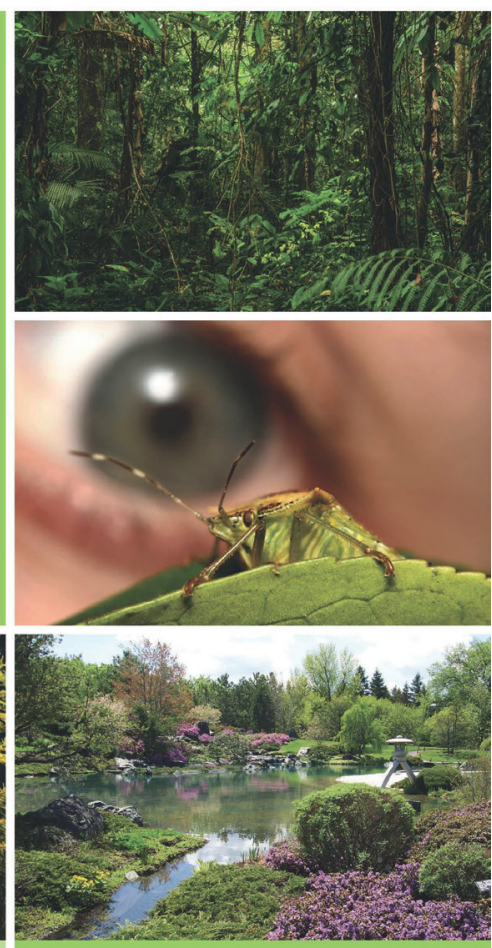

Benefits for members

The IPSN provides a number of benefits to member gardens including

- Building capacity in pest and disease surveying:

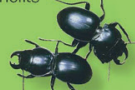

- Monitoring and diagnosis

- Contribution to international biosecurity efforts:

and

- Professional development and networking opportunities;

The network will also utilise the scientific and research significance that living collections have to offer and illustrate a commitment to plant conservation worldwide.

The IPSN \& a EUPHRESCO projoct whon is a network of organisations funding research projects and coordinating

The IPSN is funded in the UK by the Depertment for Envronmant, Food and Rural Affars (DEFFA) and is coordinated by Botenic Gardens Conservation Internationa, lead by Fera.

Fagan, L., Bthell, S., \& Dick, M. (2008). Systems for identifyng invasive threats to New Zealand flora by using overseas plantings of New Zeeland plants. In: K. J. Fourd, A. I. Popay, \& S. M. Zydenbos (Eds.), Surveilance for biosecumts: Kenis M., Roques A, Sun J. T., Fan J. T., Krichenko, N., Baranchikov Y., Tomoshevitch M., Yart A., Holmes K. and Pére C. (2011) A dalasel of potential Aslan pests of selected woody plants not yet introduced into Europe supolied as a table accossod

Find out more

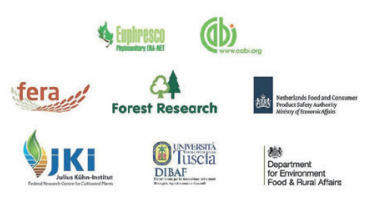

Fig. 1 IPSN overview poster developed by BGCl. 


\section{The International Plant Sentinel Network \#Spittlebughunt}

In an effort to protect the UK from Xylella fastidiosa, a bacterium causing mortality to many plant species, the \#spittlebughunt project aimed to collect information on current plant hosts of spittlebugs, which are known to carry the disease. People were invited to share information on Twitter using \#spittlebughunt, including a photo, the location, and the name of the plant hosting the spittlebugs.

\section{Volunteers}
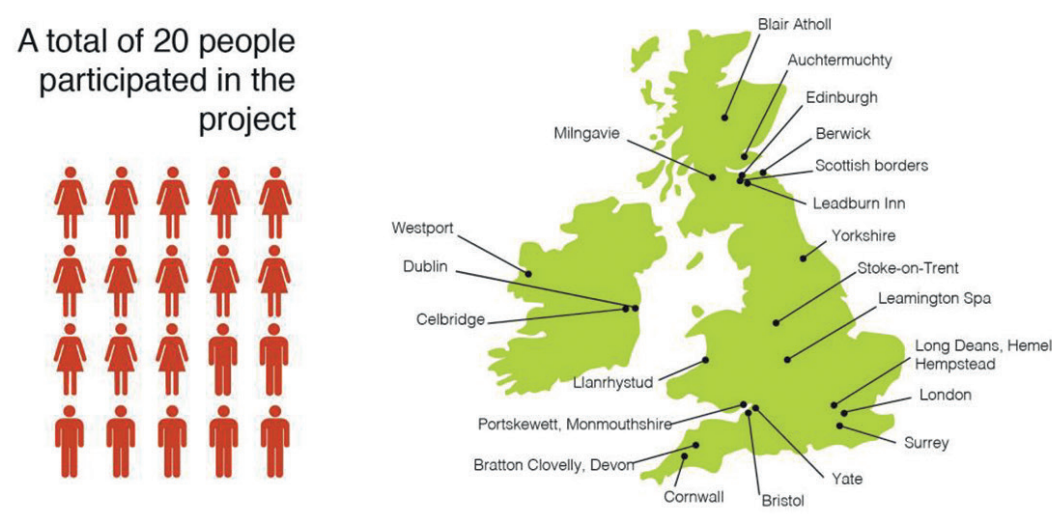

\section{Plants}

$\begin{array}{rrr}\text { Lavender (Lavandula) } & \text { Honeysuckle (Lonicera periclymenum) } \\ \text { Dock (Rumex) } & \text { Black Knapweed (Centaurea nigra) } \\ \text { Bramble (Rubus fruticosus) } & \text { Red campion (Silene dioica) } \\ \text { Nepeta 'Six Hills Giant' } & \text { Ribwort plantain (Plantago lanceolata) } \\ \text { Rosemary (Rosmarinus officinalis) } \\ \text { Salad burnet (Sanguisorba minor) } \\ \text { Strawberry (Fragaria } \times \text { ananassa) }\end{array}$

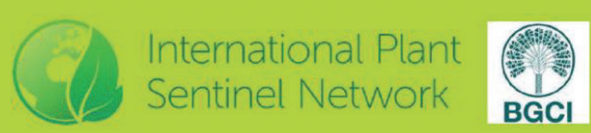

Fig. 2 Infographic displaying the results of the spittlebug survey. Infographic created by IPSN. 


\section{The IPSN UK research and development committee}

A UK IPSN R\&D committee has been

established to provide a link between BG\&A, research scientists and policy (Defra). The committee uses the UK Pest Risk Register (which includes more than 1,000 pests) to prioritise pests and pathogens of concern and to identify gaps in knowledge. The risk register is evidence-based, and many evidence gaps relate to the geographic distribution of pests of concern. The committee aims to identify evidence gaps that the IPSN could address, as well as allowing for 'horizon scanning'.

\section{Recent IPSN research activities} In 2018, the R\&D committee identified three priority topics for further research by the IPSN. These topics were selected on the basis of evidence gaps, suitability for research by BG\&A and potential for international participation and collaboration. For each pest/pathogen the main stages of the research project involved the following:

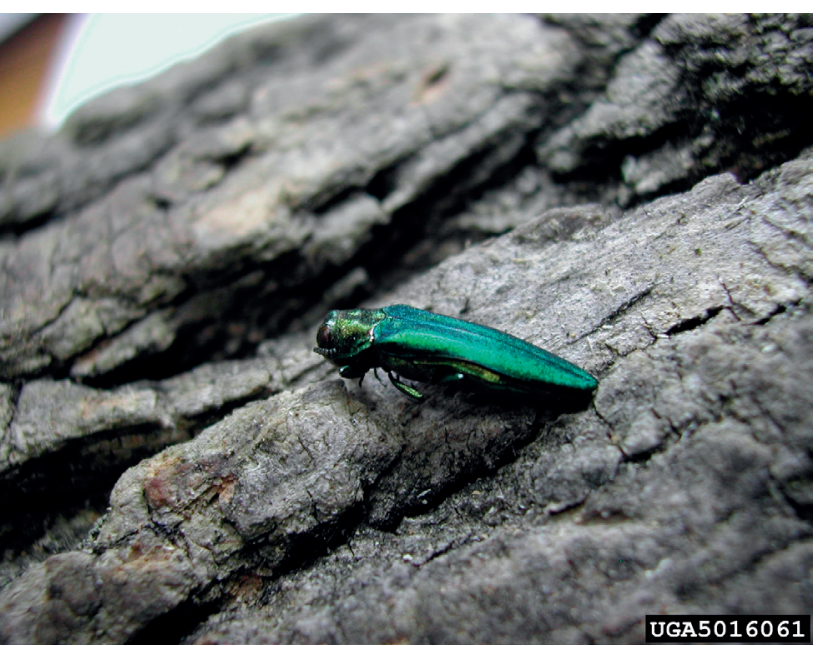

Fig. 3 Adult Agrilus planipennis (emerald ash borer) photographed on Fraxinus spp. Photo: Pennsylvania Department of Conservation and Natural Resources Forestry Archives, Bugwood.org
1. Mapping pest distribution against $B G \& A$ with host species of interest to identify target gardens

2. Developing survey resources - posters, survey materials and reporting mechanisms

3. Contacting $B G \& A$ and issuing survey resources

4. Compiling results and submitting a preliminary report of our findings to UK Risk Register scientists.

Agrilus auroguttatus (gold-spotted oak borer), A. bilineatus (two-lined chestnut borer) and Euwallacea whitfordiodendrus (polyphagous shot hole borer) on European Quercus spp.

These three wood-boring beetle pests have been shown to cause significant damage to native US oak species, by destroying the water-/nutrient-conducting tissues beneath the bark and hence girdling the tree. All three pests have caused severe economic and environmental damage in the US; however, their impact on European oak species is so far undocumented. The IPSN is therefore carrying out a survey of European oak species in US botanic gardens to gain a better understanding of the impact of these pests on European oak in order to inform the UK risk register.

\section{Results}

Pest distribution was mapped and BG\&A with European oak species in their collections within the target area were identified. Survey materials were developed and in total 26 BG\&A were contacted, 13 in California and 13 on the East Coast. In relation to the surveys in California, we identified 13 gardens with oak species native to Europe: Quercus canariensis, $Q$. cerris, $Q$. coccifera, $Q$. faginea, $Q$. frainetto, $Q$. ilex, $Q$. infectoria, $Q$. ithaburensis, $Q$. petraea, $Q$. robur, $Q$. rotundifolia, $Q$. suber and $Q$. trojana. 


\begin{tabular}{|l|l|}
\hline $\begin{array}{l}\text { Pest and disease } \\
\text { identification } \\
\text { guidance }\end{array}$ & $\begin{array}{l}\text { IPSN Guide to Bleeding Trees } \\
\text { IPSN Guide to Damage by Leaf Eaters } \\
\text { IPSN Guide to Submitting Physical Samples }\end{array}$ \\
\hline $\begin{array}{l}\text { Biosecurity } \\
\text { guidance }\end{array}$ & $\begin{array}{l}\text { IPSN Guide to Biosecurity in BG\&A } \\
\text { IPSN Guide to Plant Health Governance }\end{array}$ \\
\hline $\begin{array}{l}\text { Monitoring and } \\
\text { surveying guidance }\end{array}$ & $\begin{array}{l}\text { Plant Health Checker for Broadleaf Trees } \\
\text { Plant Health Checker for Coniferous Trees } \\
\text { IPSN Guide to Taking Photographs for Diagnostic Purposes } \\
\text { Individual fact sheets and survey forms for various pests and pathogens }\end{array}$ \\
\hline Presentations & $\begin{array}{l}\text { An Introduction to the IPSN } \\
\text { Posters }\end{array}$ \\
$\begin{array}{l}\text { IPSN Overview Poster } \\
\text { Poster Template for Emerging Pests and Pathogens } \\
\text { New and Emerging Pests of Trees (individual posters for multiple tree } \\
\text { species) } \\
\text { Xylella fastidiosa: a New and Emerging Disease of Concern } \\
\text { Rose Rosette Virus: a New and Emerging Disease of Concern } \\
\text { Sirococcus Blight of Cedars: a New and Emerging Disease of Concern } \\
\text { Spittlebug Poster }\end{array}$ \\
\hline Other & $\begin{array}{l}\text { IPSN Overview Handout } \\
\text { IPSN Overview Leaflet }\end{array}$ \\
\hline
\end{tabular}

Table 2 Key IPSN resources available on the IPSN website.

Two of these species were not evaluated in the survey. Of the 13 BG\&A identified in California, 10 participated in the project. Polyphagous shot hole borer was found at five out of the ten survey sites; no incidences of the other two pests have been recorded to date, though the project is still in its early stages. Of the East Coast BG\&A contacted, one surveyed its collection and others responded to say that the pests were not present in their areas; no incidences of any of the pests were recorded.

\section{Rose rosette virus (RRV) on Rosa spp.}

$\mathrm{RRV}$ is an emerging risk to rose cultivation and is caused by a virus in the order Bunyavirales and genus Emaravirus. It is the causal agent of rose rosette disease (RRD) and was described for the first time in the US and Canada in the 1940s; it has since spread throughout both countries. RRV is transmitted by an eriophyid mite species. The mites are transported by the wind, by insects during pollination and by contact with clothes or gardening tools. RRV causes varying symptoms on infected plants, such as lateral shoot growth, excessive thorns, witches broom, mosaic and red pigmentation, and eventually leads to the death of the plant within one to two years (Babu et al., 2017). In 2017, the virus was found in India, the first finding outside North America. The IPSN is conducting a global survey of rose collections in botanic gardens to assess the distribution of RRV outside of the known distribution area and to establish whether the finding in India was an isolated case.

\section{Results}

$B G \& A$ outside of the known distribution area of RRV were identified. Survey forms and posters were developed and sent to a large number of gardens across Europe, 
Australia and New Zealand, utilising existing botanic garden networks such as the European consortia. Survey requests were also included in newsletters such as PlantNetwork and BGCl's e-bulletin, Cultivate, in order to disseminate the request as widely as possible. With the help of national network coordinators, there was the potential for over 700 gardens to have been contacted. However, the response rate is so far somewhat disappointing, with only 17 returned forms. However, these responses cover a wide geographic area and a large number of rose cultivars (Table 3). Follow-up will continue to encourage more gardens to respond. One garden (a recent response not included in Table 3) found symptoms similar to RRV, though this has not yet been confirmed and will be followed up through photographic evidence and then physical sampling if necessary.

Hymenoscyphus fraxineus (ash dieback) and Agrilus plannipennis (emerald ash borer) on Chionanthus and Phillyrea sp.

Ash dieback is responsible for causing severe dieback on ash species across Europe (including Fraxinus excelsior and $F$. angustifolia). It is caused by the invasive fungal pathogen Hymenoscyphus fraxineus

\begin{tabular}{|c|c|c|c|}
\hline Botanic garden & Country & $\begin{array}{l}\text { Number of } \\
\text { cultivars } \\
\text { sampled }\end{array}$ & $\begin{array}{l}\text { Number of } \\
\text { suspected RRV } \\
\text { infections }\end{array}$ \\
\hline Royal Botanic Gardens Victoria & Australia & 141 & 0 \\
\hline Brisbane Botanic Gardens Mt Coot-tha & Australia & 7 & 0 \\
\hline Benalla Botanic Gardens & Australia & 6 & 0 \\
\hline National Arboretum Canberra & Australia & 5 & 0 \\
\hline $\begin{array}{l}\text { Botanic Gardens and State Herbarium } \\
\text { Adelaide }\end{array}$ & Australia & Entire collection & 0 \\
\hline Royal Tasmanian Botanic Garden & Australia & 40 & 0 \\
\hline Mackay Botanic Gardens & Australia & Entire collection & 0 \\
\hline Zagreb Botanical Garden & Croatia & Entire collection & 0 \\
\hline Tallinn Botanic Garden & Estonia & Entire collection & 0 \\
\hline Finnish Museum of Natural History & Finland & Entire collection & 0 \\
\hline $\begin{array}{l}\text { Eötvös Loránd University Botanical } \\
\text { Garden }\end{array}$ & Hungary & 110 & 0 \\
\hline VMU Kaunas Botanical Garden & Lithuania & Entire collection & 0 \\
\hline Botanische Tuin De Kruidhof, Buitenpost & Netherlands & Entire collection & 0 \\
\hline Auckland Botanic Garden & New Zealand & Entire collection & 0 \\
\hline Timaru Botanic Gardens & New Zealand & 5 & 0 \\
\hline $\begin{array}{l}\text { Conservatoire et Jardin botaniques de la } \\
\text { Ville de Genève }\end{array}$ & Switzerland & $\begin{array}{l}\text { Entire collection } \\
\text { (90 specimens) }\end{array}$ & 0 \\
\hline
\end{tabular}

Table 3 Summary of results for RRV in botanic gardens in Europe, Australia and New Zealand. 
which blocks the water transport systems in trees, causing crown dieback, lesions and the eventual death of the tree. The disease was first detected in Poland and Lithuania in the 1990s and has subsequently spread to most European countries (Broome et al., 2018). Recently, $H$. fraxineus has been detected on the non-Fraxinus hosts Phillyrea latifolia, P. angustifolia and Chionanthus virginicus in isolated locations where $H$. fraxineus spore levels were high (Forest Research, 2019). This finding is the first non-ash host record worldwide. The emerald ash borer is a wood-boring beetle native to East Asia (Fig. 3) which is currently causing significant damage to Fraxinus spp. in the USA and Canada resulting in serious economic damage as well as concern for the survival of several ash species and their associated biodiversity. The beetle was first detected in Europe in Moscow, Russia in 2003 leading to serious concerns that it could spread

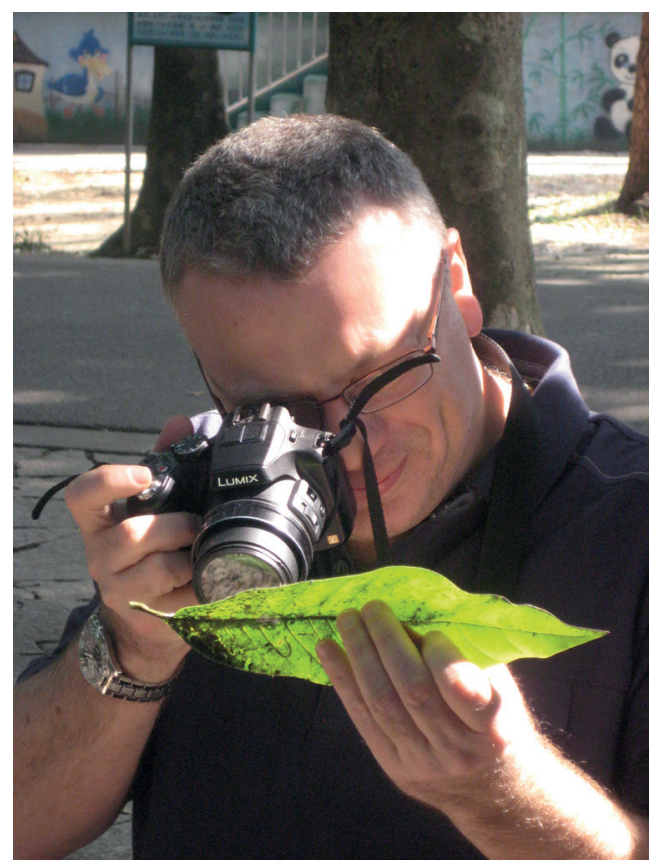

Fig. 4 Pest and disease survey during IPSN event. Photo: $\mathrm{BGCl}$. rapidly to the rest of Europe. It has since been detected in the south of Russia and in Ukraine (Orlova-Bienkowskaja et al., 2019). Emerald ash borer has also been shown to infest $C$. virginicus in an isolated case in Ohio, the first record of damage to a non-ash host (Cipollini, 2015). In combination, these two threats are a serious concern for European ash populations and the increased spread of these through non-Fraxinus hosts is extremely concerning (Hill et al., 2018). The IPSN is therefore conducting a survey to assess whether any further findings of ash dieback on Phillyrea and Chionanthus spp. and emerald ash borer on C. virginicus have been recorded.

\section{Results}

Mapping of pest distribution for these two pests was undertaken and overlaid with BG\&A containing Phillyrea and Chionanthus spp. according to PlantSearch. Separate posters for the two pests were developed alongside a combined survey form. A total of 93 BG\&A were contacted and provided with the survey materials. To date, seven completed survey forms have been returned and a number of gardens have said they will participate but cannot provide results until later in the year. It should be noted that the survey for these two pests was only recently initiated, so gardens have had little time so far to complete surveys. No positive finds for either pest have been recorded.

\section{Conclusions}

The plant collections of BG\&A around the world are an important resource, used to support research, conservation and education activities. In relation to plant health issues, monitoring plants growing outside their native regions provides a valuable opportunity to increase our knowledge of 
new pest/host relationships. While the IPSN aims to build on this and develop a global community of BG\&A focused on plant health issues, it is also clear that many botanic gardens are under-resourced and lack the required expertise to carry out regular pest and disease monitoring and surveying. However, as a networking organisation, $\mathrm{BGCl}$ firmly believes that these challenges can be overcome through working together and sharing experiences and information (Fig. 4). We encourage interested gardens to consider joining the IPSN and becoming part of our global effort to reduce the risk alien invasive pests pose to our native floras.

\section{References}

ANAGNOSTAKIS, S.L. (1987). Chestnut blight: the classical problem of an introduced pathogen. Mycologica, 79: 23-37. doi:10.2307/3807741 .

BABU, B., WASHBURN, B.K., ERTEK, T.S., MILLER, S.H., RIDDLE, C.B., KNOX, G.W., OCHOA-CORONA, F.M., OLSON, J., KATIRCIOĞLU, Y.Z. \& PARET, M.L. (2017). A field based detection method for Rose rosette virus using isothermal probe-based Reverse transcription-recombinase polymerase amplification assay. Journal of Virological Methods, 247: 81-90. doi:https://doi.org/10.1016/j. jviromet.2017.05.019.

BARHAM, E., SHARROCK, S., LANE, C. \& BAKER, R. (2015). An International Plant Sentinel Network. Sibbaldia, 13: 83-98.

BROOME, A., RAY, D., MITCHELL, R. \& HARMER, R. (2018). Responding to ash dieback (Hymenoscyphus fraxineus) in the UK: woodland composition and replacement tree species. Forestry: An International Journal of Forest Research, 92(1): 108-119. doi:https://doi.org/10.1093/ forestry/cpy040.

CIPOLLINI, D. (2015). White fringetree as a novel larval host for emerald ash borer. Journal of Economic Entomology, 108(1): 370-375. doi:10.1093/jee/tou026.

FOREST RESEARCH (2019). Chalara ash dieback on different ash species and non-ash hosts. Available online: www.forestresearch.gov.uk/news/ chalara-ash-dieback-different-ash-species-and-nonash-hosts (accessed August 2019).

HILL, L., HEMERY, G., HECTOR, A. \& BROWN, N. (2018). Maintaining ecosystem properties after loss of ash in Great Britain. Journal of Applied Ecology, 56(2): 282-293. doi:https://doi. org/10.1111/1365-2664.13255.

IPSN (2014). International Plant Sentinel Network The Network. Available online: www.plantsentinel. org/the-network (accessed July 2019).

MANSFIELD, S., MCNEILL, M., AALDERS, L.T., BELL, N.L., KEAN, J.M., BARRATT, B.I.P., BOYD-WILSON, K. \& TEULSON, D.A.J. (2019). The value of sentinel plants for risk assessment and surveillance to support biosecurity. Neobiota, 48: 1-24. doi:10.3897/neobiota.48.34205.

MOUNCE, R., SMITH, P. \& BROCKINGTON, S. (2017). Ex situ conservation of plant diversity in the world's botanic gardens. Nature Plants, 3: 795-802.

ORLOVA-BIENKOWSKAJA, M.J., DROGVALENKO, A.N., ZABULUEV, I.A., SAZHNEV, A.S., PEREGUDOVA, E.Y., MAZUROV, S.G., KOMAROV, S.G. \& BIEŃKOWSKI, A.O. (2019). Bad and good news for ash trees in Europe: alien pest Agrilus planipennis has spread to the Ukraine and the south of European Russia, but does not kill Fraxinus excelsior in the forests. bioRxiv, 689240. doi:10.1101/689240. 